\title{
GIANT AMELOBLASTOMAS: CLINICO-PATHOLOGICAL REVIEW OF IMPLICATIONS OF TUMOR GROWTH RATE
}

\author{
Ezekiel T. Adebayo' ${ }^{\text {, Afolake S. Salami², Emmanuel A. Adelusi', Benjamin Fomete }{ }^{3} \text {, Adetayo 0. Aborisade }}{ }^{4}$ \\ 'Department of Oral and Maxillofacial Surgery, University of Medical Sciences, Ondo City, Nigeria \\ 2Department of Oral and Maxillofacial Pathology, Radiology and Medicine, University of Medical Sciences, Ondo, Nigeria \\ ${ }^{3}$ Maxillofacial Unit, Ahmadu Bello University/Teaching Hospital, Zaria, Nigeria \\ ${ }^{4}$ Department of Oral Pathology and Radiology, Bayero University/Aminu Kano University Teaching Hospital, Kano, Nigeria
}

\begin{abstract}
INTRODUCTION: Limited number of publications describe the influence of tumor growth rate on clinicopathologic features of giant (extreme or gigantic) forms of ameloblastoma (GA). This paper explores the relationship between these two factors.

ОвJеCтIVEs: To determine the relationship between tumor growth rate of GA and clinico-pathologic factors such as age, gender and histopathologic subtype.

MATERIAL AND METHODs: GA cases were selected from the published literature based on the criteria described by Kanoi et al., availability of clinical data, such as age and gender of patient, duration of lesion, and three-dimensional size (volume) of specimen after surgical resection. Data collected were used to calculate individual tumor growth rate using modified formula of Merhara et al. Clinico-pathological features and calculated tumor growth rates were compared with other publications.

RESULTS: In total, 18 reviewed patients were included into this study, from sixteen publications with 17 patients who fitted the selection criteria and one case of GA from our center. There was gender balance (male : female ratio, $1: 1$ ), with age ranging 19-73 years (mean, $44.2 \pm 15.6$ years). Mean age of patients with GA was much higher than in non-GA cases, with statistically significant difference $(p=0.02)$. There was mild positive correlation $(r=0.219)$ between surgical volume and duration of tumor, but it was not statistically significant $(p=0.382)$. Mean specific growth rate was $85 \% \pm 40.1 \%$ /year (range, $19.9-170 \%$ /year). Comparison of SGR with other clinico-pathological parameters of GA revealed no statistical significance.

ConcLusions: GA occurred at a higher mean age than other forms, and the mean tumor growth rate was $85 \%$ per year. This had no statistical relationship to clinico-pathological characteristics studied.
\end{abstract}

KEY wORDS: ameloblastoma, giant lesion, specific tumor growth rate, poverty, surgery.

J Stoma 2020; 73, 5: 270-275

DOI: https://doi.org/10.5114/jos.2020.100533

\section{INTRODUCTION}

The recent histological classification of odontogenic tumors perceives ameloblastoma as a histologically benign, locally invasive neoplasm of epithelial odontogenic origin, which occurs in conventional, unicystic, and extraosseous/ peripheral types [1]. The tumor is rare, accounting for $1 \%$ of all jaw cysts and tumors [2]. Most cases arise from the mandible and maxilla, and involve persons between the third and fourth decades of life, but without a clear sexual predilec-

\section{JOURNAL OF} STOMATOLOGY 
tion [3]. The conventional type is the most common (85\% of prevalence), followed by the unicystic variety, with the peripheral type accounting for only $1-2 \%$ of cases [3]. Histopathologic subtypes are one third follicular, one third plexiform, and the rest of cases comprise other variants $[3,4]$.

While histologically benign, ameloblastoma is an odontogenic tumor with varying biological behavior [5], ranging from cystic expansion with minimal facial deformity, to an aggressive solid mass, causing malnutrition and even death [6]. In view of this spectrum of behaviors, it is important to differentiate types of tumor in order to deliver patient-specific treatment [5].

As reported in the literature, only some ameloblastoma grow to be huge, massive, neglected, extreme, giant, or gigantic. These are described as giant ameloblastoma (GA), which cause poor facial esthetics [6], metabolic derangement like hypoproteinemia [7], hypercalcemia, leukocytosis, elevated tumor markers via production of parathyroid hormone protein, and granulocyte colony-stimulating factor [8]. Moreover, GAs are more difficult to manage apart from other cases of ameloblastoma [9-11]. Establishing the growth rate of GA and its relationships could assist in the management of these lesions and prognosing the outcomes. The hypothesis of this study was that specific growth rate (SGR) of GA has a relationship to gender, age of occurrence, and histopathologic subtype. Therefore, the purpose of this study was to test the hypothesis that SGR of GA is associated with gender, age, and histopathologic type.

\section{OBJECTIVES}

To determine the relationship between tumor growth rate of GA and clinico-pathologic factors such as age, gender and histopathologic subtype.

\section{MATERIAL AND METHODS}

\section{SEARCH STRATEGY AND SELECTION CRITERIA}

The current study was a review of published literature on GA cases. Using PubMed, Google scholar, and Web of Science, studies in English on extreme, gigantic, neglected, or GA were reviewed from 1970 to 2019. The inclusion criteria were reported cases of GA, with all three dimensions of the tumor (i.e., length $\times$ width $\times$ height) available from post-operative (surgical) sampling, and duration of symptoms. The excluded studies were those reporting less than three dimensions of a surgical specimen, those with clinical or radiological dimensions only, cases of ameloblastic carcinoma, malignant ameloblastoma, recurrent ameloblastoma, in vitro growth, or molecular studies.

\section{DATA EXTRACTION AND ANALYSIS}

Information, such as author(s)/year of publication, gender and age of patient, dimensions of surgical speci- men, duration of lesion, and histopathologic subtype were recorded in a data abstraction sheet. Surgical tumor volume dimensions from each study, and the duration of symptoms were juxtaposed to derive the specific growth rate (SGR; growth \% per year) per case using Mehrara et al. [12] tumor growth calculation, modified by Chae et al. [13], using the following formula:

$$
\mathrm{SGR}=\mathrm{In}(\mathrm{V} 2 / \mathrm{V} 1) / \mathrm{T} 2-\mathrm{T} 1
$$

where $V 1$ was considered as " 1 " and $T 1$ as " 0 ".

Data were analyzed using STATA (version 14; StataCorp, College Station, Texas, USA). Descriptive statistics were evaluated for age and gender variables. Age was categorized into three groups as 0-20 years, 21-40 years, and 41 years and older. The prevalence of gender and age in the groups was determined and expressed in frequencies as percentages. Means and standard deviations were used for the age, while proportions were used for categorical variables. An independent $t$ test and ANOVA were applied to compare differences in the mean age with $95 \%$ confidence interval (CI), and were performed after Levene's test and Shapiro-Wilk's test had been used to confirm homogeneity of variance and normality of distribution, respectively. Welch's t test and ANOVA were applied in case of any deviation from normality of data or homogeneity of variance; otherwise, non-parametric Kruskal-Wallis' equality of populations' rank test was utilized to determine the average of means between variables.

The calculated SGR was used as a continuous variable and then categorized into two parameters $(<100 \%$ per year and $\geq 100 \%$ ) to compare its association with gender, age groups, and main histologic types (plexiform vs. follicular), with the $\chi^{2}$ test. All tests were carried out with significance accepted as $p \leq 0.05$.

\section{RESULTS}

They were 17 patients from 16 publications [6-8, 14-27] selected, with post-surgical specimen volume dimensions and duration of symptoms recorded. One case was added from own center, making 18 GA patients for this study. SGR was calculated for each patient. Table 1 shows the data abstracted from included studies [7, 13-27]. GA occurred equally in males and females (ratio, $1: 1$ ), while the age ranged from 19 to 73 years (mean, $44.2 \pm$ 15.6 years). As compared to the mean age of 35.9 years reported by Reichart et al. [3], the mean age of GA from the present study was higher with statistically significant difference $(p=0.02)$. There was no statistically significant difference $(p=0.21, \mathrm{df}=16)$ between the mean ages of males ( $48.9 \pm 17.0$ years; $95 \%$ CI: 35.8-61.9) and females (39.6 \pm 13.4 years; 95\% CI: 29.3-49.8). Various age groups included patients with $0-20$ years $(1 ; 5.6 \%)$, $21-40$ years $(6 ; 44.4 \%)$, and $>40$ years $(9 ; 50 \%)$. Mean 
TABLE 1. Determination of specific growth rate (SGR) of some giant ameloblastoma

\begin{tabular}{|c|c|c|c|c|c|c|c|}
\hline $\begin{array}{l}\text { Serial } \\
\text { No. }\end{array}$ & $\begin{array}{l}\text { Author(s), year of publication } \\
\text { [ref] }\end{array}$ & $\begin{array}{l}\text { Gender/ } \\
\text { age } \\
\text { (years) }\end{array}$ & $\begin{array}{c}\text { Dimensions } \\
\text { of surgical } \\
\text { specimen }\left(\mathrm{cm}^{3}\right)\end{array}$ & $\begin{array}{l}\text { Duration } \\
\text { of lesion } \\
\text { (years) }\end{array}$ & $\begin{array}{c}\text { SGR } \\
\text { (\% per year) }\end{array}$ & Location* & $\begin{array}{l}\text { Histologic } \\
\text { subtype }\end{array}$ \\
\hline 1 & Rambo et al., 1977 [14] & $F / 41$ & $21 \times 15 \times 10$ & 14 & 57.6 & $\begin{array}{l}\text { Posterior/anterior/ } \\
\text { posterior mandible }\end{array}$ & $\mathrm{N} / \mathrm{A}$ \\
\hline 2 & Osaki et al., 1985 [15] & $\mathrm{F} / 30$ & $14 \times 13 \times 12$ & 7 & 109.8 & $\begin{array}{l}\text { Posterior/anterior } \\
\text { mandible }\end{array}$ & Plexiform \\
\hline 3 & Ueyama et al., 1995 [16] & $M / 73$ & $10 \times 9 \times 7.5$ & 10 & 65.1 & $\begin{array}{l}\text { Posterior/anterior/ } \\
\text { posterior mandible }\end{array}$ & Plexiform \\
\hline 4 & Gordy et al., 1996 [17] & $F / 19$ & $8 \times 6 \times 6$ & 5 & 113.3 & Posterior mandible & Follicular \\
\hline 5 & Hughes et al., 1999 [18] & $F / 53$ & $15.2 \times 11.4 \times 12$ & 6 & 127.3 & $\begin{array}{l}\text { Posterior/anterior } \\
\text { mandible }\end{array}$ & Plexiform \\
\hline 6 & Mukhopadhyay et al., 2005 [19] & $M / 32$ & $25 \times 15 \times 10$ & 7 & 117.5 & $\begin{array}{l}\text { Posterior/anterior/ } \\
\text { posterior mandible }\end{array}$ & Acanthomatous \\
\hline 7 & Kasbeka et al., 2011 [20] & $M / 30$ & $12 \times 8 \times 6$ & 5 & 127.2 & $\begin{array}{l}\text { Posterior/anterior } \\
\text { mandible }\end{array}$ & $\begin{array}{c}\text { Follicular/ } \\
\text { acanthomatous }\end{array}$ \\
\hline 8 & Acharya et al., 2011 [7] & $F / 35$ & $15 \times 12 \times 10$ & 10 & 74.9 & $\begin{array}{l}\text { Posterior/anterior/ } \\
\text { posterior mandible }\end{array}$ & Plexiform \\
\hline 9 & Chauhan and Guruprasad, 2011 [21] & $\mathrm{F} / 42$ & $15 \times 14 \times 10$ & 4.5 & 170.0 & $\begin{array}{l}\text { Posterior/anterior } \\
\text { mandible }\end{array}$ & Plexiform \\
\hline 10 & Ota et al., 2012 [8] & $F / 32$ & $27.2 \times 20.3 \times 15.1$ & 10 & 90.3 & $\begin{array}{l}\text { Posterior/anterior } \\
\text { mandible }\end{array}$ & Acanthomatous \\
\hline 11 & Hunasgi et al., 2013 [22] & $F / 39$ & $12 \times 9 \times 10$ & 10 & 69.8 & $\begin{array}{l}\text { Posterior/anterior } \\
\text { mandible }\end{array}$ & Granular cell \\
\hline 12 & Choudhary et al., 2014 [23] & $F / 65$ & $14 \times 11 \times 8$ & 10 & 71.2 & $\begin{array}{l}\text { Posterior/anterior/ } \\
\text { posterior mandible }\end{array}$ & $\begin{array}{c}\text { Follicular/ } \\
\text { acanthomatous }\end{array}$ \\
\hline 13 & Jain et al., 2014 [24] & $M / 38$ & $15 \times 14 \times 15$ & 12 & 67.2 & $\begin{array}{l}\text { Posterior/anterior/ } \\
\text { posterior mandible }\end{array}$ & Acanthomatous \\
\hline 14 & Raghunath et al., 2014 [25] & $M / 60$ & $17 \times 11 \times 9$ & 30 & 24.7 & $\begin{array}{l}\text { Posterior/anterior } \\
\text { mandible }\end{array}$ & $\begin{array}{c}\text { Follicular/ } \\
\text { granular cell } \\
\text { /acanthomatous }\end{array}$ \\
\hline 15 & Duc et al., 2018 [26] & $M / 67$ & $19 \times 12 \times 13$ & 40 & 19.9 & $\begin{array}{l}\text { Posterior/anterior/ } \\
\text { posterior mandible }\end{array}$ & N/A \\
\hline 16 & Duc et al., 2018 [26] & $M / 48$ & $10 \times 12 \times 12$ & 30 & 65.1 & $\begin{array}{l}\text { Posterior/anterior/ } \\
\text { posterior maxilla }\end{array}$ & $N / A$ \\
\hline 17 & Nariai et al., 2019 [27] & $M / 62$ & $13.5 \times 9 \times 8$ & 7 & 98.3 & Posterior mandible & $\begin{array}{c}\text { Follicular/ } \\
\text { Desmoplastic }\end{array}$ \\
\hline 18 & Own case, 2020 & $M / 30$ & $43 \times 38 \times 17$ & 10 & 102.3 & $\begin{array}{l}\text { Posterior/anterior/ } \\
\text { posterior mandible }\end{array}$ & Follicular \\
\hline
\end{tabular}

*Posterior was behind the canine teeth, anterior was between the canine teeth

tumor volume was $3624.4 \pm 6294.4 \mathrm{~cm}^{3}$ (range, 288$\left.27778 \mathrm{~cm}^{3}\right)$. There was no statistically significant difference $(p=0.72)$ in the mean surgical specimen volumes of males $\left(4776.4 \pm 8701.3 \mathrm{~cm}^{3}\right)$ and females $(2472.4 \pm$ $2343.7 \mathrm{~cm}^{3}$ ). The mean tumor duration for the $18 \mathrm{pa}$ tients included was 12.5 years. There was a mild positive correlation $(r=0.219)$ between surgical volume and duration of tumor, but it was not statistically significant ( $p=0.382$ ). The range of SGR was $19.9-170 \%$ per year (mean, $85 \% \pm 40.1 \% /$ year). Comparison of SGR versus gender, age group, and histological growth pattern of GA did not yield any statistical significance. Summary of the comparison is presented in Table 2.

\section{DISCUSSION}

There is controversy about the definition of GA. Chaine et al. [9] characterized GA as mandibular lesions of a large size ( $>5 \mathrm{~cm}$ in length). However, this definition did not clarify whether the measurement was based on clinical, radiological findings, or the post-surgical specimen. Also, the basis for this length was not stated. 
In another study, Kanoi et al. [11] described GA resulting in a post-surgical defect $>7 \mathrm{~cm}$ in length after segmental resection and the bone defect involving central mandibular segment. The bases for their definition were clinical objectivity and simplicity in better doctors' communication, having a direct influence on decision-making and GA management. The present study selected GA cases based on the criteria of Kanoi et al. [11], and cases after 1970 were chosen for evaluation because the earliest World Health Organization classification of odontogenic tumors was published in 1971.

In the literature, GA dimensions have been given from clinical, radiological, and post-surgical measurements. However, these dimensions could vary even for the same patient. Raghunath et al. [25] reported a patient whose GA measured $18 \mathrm{~cm} \times 12 \mathrm{~cm} \times 11 \mathrm{~cm}$ clinically, while the post-surgical specimen was $17 \mathrm{~cm}$ $\times 11 \mathrm{~cm} \times 9 \mathrm{~cm}$. In another paper, Gupta et al. [28] described a patient whose GA measured $16 \mathrm{~cm} \times 13 \mathrm{~cm}$ $\times 12.5 \mathrm{~cm}$ clinically, $20 \mathrm{~cm} \times 13 \mathrm{~cm} \times 13 \mathrm{~cm}$ on a CT, and $12 \mathrm{~cm} \times 10 \mathrm{~cm}$ from the post-surgical specimen. Based on these differences between various modalities of measurement, only publications with three dimensional post-surgical measurements were evaluated to ensure uniformity. The range of volumes recorded for various cases of GA in this study were $288 \mathrm{~cm}^{3}$ to $27778 \mathrm{~cm}^{3}$ (mean, $3624.4 \pm 6294.4 \mathrm{~cm}^{3}$ ). There was no comparable literature on mean volumes for resected GA; hence, the is a need for future reports of GA to provide threedimensional measurements of post-surgical specimens to improve comparability of these rare lesions.

In a study of 100 cases of ameloblastoma, Effiom and Odukoya [5] reported almost equal gender ratio (male : female ratio, $1: 0.9)$ for ameloblastoma. In a smaller sample consisting of 16 cases of GA, Chae et al. [13] observed more females than males (ratio, $2.2: 1$ ). The present study showed no sexual predilection for GA, which was similar to other conventional (formerly called "solid- multicystic") ameloblastoma [1,3]. Ameloblastoma is known to occur at any age, rarely at the extremes of life, but mostly between the third and fourth decades of life [3]. The 18 patients reviewed in Table 1 had a mean age of 44.2 years, with $50 \%$ (9) of cases aged above 40 years of age. On statistical analysis, the mean age of patients with GA was much higher than those described by Reichart et al. [3], with statistically significant difference $(p=0.02)$. Therefore, GA appears to occur in an older age group than other forms of ameloblastoma.

Despite significant morbidity and mortality associated with this neoplasms, there are very few reports on the growth rate of ameloblastomas. Effiom and Odukoya [5] evaluated monthly growth rate of solid, multicystic (now described as "conventional") ameloblastoma to be $0.81 \mathrm{~cm}$ per month, which was higher than that for the peripheral type $(0.17 \mathrm{~cm}$ per month $)$. They also found that tumor growth was slower in males than females, while the latter presented lower tumor volumes.
TABLE 2. Summary of SGR versus gender, age group, and tumor subtype

\begin{tabular}{|l|c|c|c|}
\hline P-value & Gender & \multicolumn{1}{c}{ Age group } & Growth pattern \\
\hline SGR & 0.16 & 0.43 & 0.38 \\
\hline SGR (2) & 0.63 & 0.22 & 0.15 \\
\hline
\end{tabular}

$S G R(2)$ is SGR as a categorical variable

However, their results lacked clarity on study sample collection criteria; it was based on mixture of clinical and radiological measurements and assumed that ameloblastoma followed a linear growth pattern [13].

Available evidence shows that ameloblastoma initially exhibits slow growth, which later accelerates in weeks $[29,30]$ or in years [15]. Chae et al. [13] systematically reviewed natural history and growth pattern of 16 cases of ameloblastoma. Using a natural exponential growth formula for carcinomas proposed by Mehrara et al. [12], they obtained the mean SGR of ameloblastoma to be 87.84\% per year (range, 37.37-169.68). An important drawback of Chae et al. [13] findings was using a combination of clinical, radiological, and surgical specimen sizes of ameloblastoma. It had been previously observed that there could be differences in the measured sizes using these modalities even for the same lesion, as reported by Raghunath et al. [25] and Gupta et al. [28]. The mean SGR from our study was $85 \%$ per year, which was close to the $87.84 \%$ per year reported by Chae et al. [13]. However, our finding was more representative of the SGR of GA due to better sampling criteria.

In our study, there was no statistically significant association between SGR and gender and age group (Table 2). Chae et al. [13] found the most statistical significance ( $p=0.14)$ in cases when ameloblastoma of the plexiform/ follicular histologic subtypes compared to other subtypes of ameloblastoma were analyzed in association with SGR (as a categorical variable). However, they noted that the results could be due to a low sample size. In Table 2, the most statistically significant difference $(p=0.15)$ was shown when tumors exhibiting follicular and plexiform patterns were compared based on SGR as a categorical variable. It is known that ameloblastomas are mostly (66.6\%) of follicular or plexiform histopathologic subtypes, while the rest (33.3\%) are acanthomatous, granular cell, basaloid, and desmoplastic subtypes [1].

GAs present as large, gigantic, or extreme swellings [6-11, 14-27]. They can occur in jaw, but are more frequent in the mandible than the maxilla $[1,3]$. In this study, most GAs (94.4\%) occurred in the mandible (Table 1). Due to their large sizes, GAs causes loss of occlusal function, and mastication, speech, and breathing difficulties [6]. There is also an increased risk of hemorrhage from skin ulceration and symptoms of anemia [7]. As found in this review, GAs present as solid, multicystic lesions in radiologic appearance, with fenestration of cortical bone in multiple places [7, 19, 21]. 
In spite of large sizes of GA, the treatment goal aims at complete tumor removal, and functions and appearance restoration. In order to remove the tumor completely, a surgical resection with $1.0-1.5 \mathrm{~cm}$ of normal bone margin is used to ensure adequate tumor removal, as the tumor infiltrates cancellous bone beyond the radiological margins [31, 32].

Early radical resection is especially important in the maxilla because of its more aggressive behavior. Anatomically, the maxilla has thinner cortical plates and abundant cancellous bone, while the thick cortical bone in the mandible decelerates tumor growth. Furthermore, maxillary ameloblastoma can invade the central nervous system $[33,34]$.

Jawbone resection for GA can cause dysfunctions in appearance, speech and swallowing mastication with saliva drooling. These can severely reduce the post-surgical quality of life of patients $[11,32]$. To decrease these sequelae, immediate or delayed reconstruction are necessary. While an immediate reconstruction is favored by many $[7,9,11]$, it is not always possible due to patient and technical factors [35]. Immediate reconstruction reduces costs, decreases number of surgeries, and allows earlier prosthetic rehabilitation [36]. However, treatment of GA need an individualized, systematic, and multidisciplinary approach, with an involvement of related fields, such as maxillofacial surgery, ENT, oral implantology, prosthodontics, and radiology [32]. The ideal reconstruction is observed with a bone graft or flap, distraction osteogenesis, and dental prosthesis for rehabilitation [37].

There are some challenges in the surgical management of GA. These include the risk of airway compromise, possibility of severe hemorrhage from the external carotid artery and pterygoid plexus of veins, post-operative infections, and death. To reduce the risk to the airway, suturing the muscles of tongue to a Kirschner wire or leaving the nasotracheal tube in a position for 36 hours [38] as well as preoperative tracheostomy [7] have been utilized. The use of a tongue stitch to secure the tongue either on an artery clip or on a syringe has also been described [39]. To prevent severe hemorrhage, ligation of the external carotid arteries has been suggested, but Acharya et al. [7] did not support this technique due to risk of cutaneous necrosis.

The technical challenge associated with surgical management of GA requires mandatory follow-up of treated patients for a prolonged period, possibly for life. More than $50 \%$ of ameloblastoma recurrences are observed within 5 years of treatment $[3,40]$. However, life-long review of treated patients is advisable, as a recurrence after 20,30, or 49 years have been reported in bone or surrounding soft tissues [39-42]. Granular and follicular variants of the tumor have been reported to exhibit higher recurrence rate $[41,42]$. To a large extent, a recurrence occurs due to inadequate tumor clearance at primary surgery. A recurrence rate of $4.5 \%$ after seg- mental jaw resection has been reported [43]. However, in the present study, no recurrence after the treatment of GAs lesions was reported (Table 1).

\section{CONCLUSIONS}

GAs are rare conventional ameloblastoma that are extremely big and disfigure the patient's appearance. Most cases of GA present at 44 years of age, unlike other forms of conventional ameloblastoma, which occur about 10 years earlier. The specific tumor growth rate is $85 \%$ per year, and this shows mild correlation with duration before presentation. The management of GA is challenging due to various difficulties, including the control of airway, risk of intra-operative bleeding, reconstruction of the jawbone, and lost dentition to restore function and appearance. Surgical resection and immediate reconstruction is the ideal treatment, and life-long follow-up needs to be maintained in order to detect a recurrence.

\section{CONFLICT OF INTEREST}

The authors declare no potential conflicts of interest with respect to the research, authorship, and/or publication of this article.

\section{References}

1. El-Naggar AK, Chau JKC, Grandis JR, Takata T, Slootweg P (eds.) Odontogenic and maxillofacial tumors. WHO classification of Head and Neck Tumors. $4^{\text {th }}$ ed. Lyon; IARC 2017; 205-260.

2. Batsakis J. Tumors of the head and neck. $2^{\text {nd }}$ ed. Baltimore; Williams and Wilkins, 1979: 531-61.

3. Reichart PA, Philipsen HP, Sonner S. Ameloblastoma: biological profile of 3677 cases. Eur J Cancer B Oral Oncol 1995; 31B: 86-99.

4. Cadavid AMH, Araujo JP, Coutinho-Camillo CM, Bologna S, Lemos Junior CA, Lourenço SV. Ameloblastoma, current aspects of new WHO classification in an analysis of 136 cases. Surg Exp Path 2019; DOI: doi.org/10.1186/s42047-019-0041-z.

5. Odukoya O, Effiom OA. Clinico-pathological study of 100 Nigerian cases of ameloblastoma. Niger Postgrad Med J 2008; 15: 1-5.

6. Etetafia MO, Arisi AA, Omoregie OF. Giant ameloblastoma mortality: a consequence of ignorance, poverty and fear. BMJ Case Rep 2014; DOI: doi:10.1136/bcr-2013-201251.

7. Acharya S, Joshi A, Tayaar AS, Gopalkrishnan K. Extreme ameloblastoma of the mandible with hypoproteinemia. A case report and review of clinicopathological features. J Clin Exp Dent 2011; 3: e343-347.

8. Ota Y, Aoki T, Otsuru M, Hirabayashi K, Nakamura N, Tsukinoki K. Huge ameloblastoma associated with hypercalcemia, leucocytosis and elevated tumor markers via production of parathyroid hormone protein and granulocyte colony-stimulating factor. J Oral Maxillofac Surg 2012; 70: 1380-1385.

9. Chaine A, Pitak-Arnnop P, Dhanuthai K, Ruhin-Poncet B, Bertrand $\mathrm{C}$, Bertolus $\mathrm{C}$. A treatment algorithm for managing giant mandibular ameloblastoma: 5-year experiences in a Paris university hospital. Eur J Surg Oncol 2009; DOI: 10.1016/j.ejso.2009. 04.006.

10. Li X, Zhu K, Liu F, Li H. Assessment of quality of life in giant ameloblastoma adolescent patients who have had mandible defects 
reconstructed with a free fibula flap. World J Surg Oncol 2014; 12: 201.

11. Kanoi AV, Banerjee T, Sundaramurthy N, Sarkar A, Kanoi P, Saha S. Defining giant mandibular ameloblastoma - is a separate clinica sub-entity warranted? Indian J Plast Surg 2018; 51: 208-215.

12. Mehrara E, Forssell-Aronsson E, Bemhardt P. Objective assessment of tumor response to therapy based on tumor growth kinetics. Br J Cancer 2011; 105: 682-686.

13. Chae MP, Smoll NR, Hunter-Smith DJ, Rozen WM. Establishing the natural history and growth rate of ameloblastoma with implications for management: systematic review and meta-analysis. PLoS One 2015; 10: e0117241.

14. Rambo VB, Davies NE. Giant ameloblastoma. JAMA 1977; 238 : 418-420.

15. Osaki T, Ryoke K, Nagami T, Ogawa T, Hamada T. Ameloblastoma with hypoproteinemia due to protein leakage. Int J Oral Surg 1985; 14: 302-306

16. Ueyama Y, Tsukamoto G, Matsumura T. Gigantic ameloblastoma of the mandible complicating hypoproteinenmia: case report. J Craniomaxillofac Surg 1995; 23: 47-49.

17. Gordy FM, Holder R, O'Carroll MK, Krolls SO. Growth of an ameloblastoma during pregnancy: opportunity lost? Spec Case Dentist 1996; 16: 199-203.

18. Hughes CA, Wilson WR, Olding M. Giant ameloblastoma: Report of an extreme case and description of its treatment. Ear Nose Throat J 1999; 78: 568-574.

19. Mukhophadhay S, Raha K, Mondal SC. Huge ameloblastoma of jaw- a case report. Indian J Otolaryngol Head Neck Surg 2005; 57: 247-248.

20. Kasbeka VG, Oberoi V, Mishra A, Shah RP, Jagde MV. Giant am eloblastoma of the mandible. Bombay Hosp J 2011; 53: 527-529.

21. Chauhan DS, Guruprasad Y. Plexiform ameloblastoma of the mandible. J Clin Imaging Sci 2011: 1: 61

22. Hunasgi S, Konem A, Chauhan DS, Guruprasad Y. Rare giant granular cell ameloblastoma: a case report and immunohistochemical study. Case Rep Dent 2013; 2013: 372781.

23. Choudhary K, Shah H, Panda S, Gandhi S. Giant ameloblastoma: a rarity. Indian J Cancer 2014; 51: 592-593.

24. Jain A, Gupta N, Shukla H, Tadaiya M. Giant anterior ameloblastoma managed by wide excision mandibulectomy with intraoral mucosal closure and skin defect coverage by deltopectoral flap. South Asian J Cancer 2014; 3: 187-188.

25. Raghunath V, Rath R, Kamal F, Misra SR. Massive granular cell ameloblastoma with dural extension and atypical morphology. Contemp Clin Dent 2014; 5: 535-538.

26. Duc QN, Son Tai N, Lam NV, BaeKyu K. Reconstruction of the maxillofacial defect after extensive resection of the giant ameloblastoma using osteocutaneous fibular free flap. Biomed J Sci Tech Res 2018; 5: 4772-4775.

27. Nariai Y, Yanai C, Iwahashi T, Kanno T. Clinical features of giant hybrid ameloblastoma of the mandible: a case report with long term observation of natural growth before treatment. Oral Maxillofac Surg Cases 2019; 5: 100116.

28. Gupta Y, Mennon MJ, Hussain N, Gahine R. Giant plexiform unicystic ameloblastoma: a rare variant of ameloblastoma. Indian J Pathol Oncol 2016; 3: 522-525.

29. Pramulio TH, Said HM, Kozlowsi K. Huge ameloblastoma of the jaw (report of three cases). Australas Radiol 1985; 29: 308-310.

30. Rajaonarison Ny Ony N, Randriamorolahy A, Randrianjanahary OM, Ahmad A, Bruenton JN. Giant ameloblastoma. Clin Imaging 2012; 36: 146-148

31. Pogrel MA, Montes DM. Is there a role for enucleation in the management of ameloblastoma? Int J Oral Maxillofac Surg 2009; 38: 807-812.

32. Zhang Z, Pan J, Huang X, Chen S. Individualized treatment for the mandibular segment defect: A case report. Indian J Surg 2015 (Suppl 1): S56-S58.

33. Sehdev MK, Huvos AG, Strong EW, Gerold FP, Willis GW. Proceedings: ameloblastoma of maxilla and mandible. Cancer 1974 33: 324-333.
34. Nastri AL, Wiesenfeld D, Radden BG, Eveson J, Scully C. Maxillary ameloblastoma: a retrospective study of 13 cases. Br J Oral Maxillofac Surg 1995; 33: 28-33.

35. Rakotoarison RA, Ratoiondrainy W, Randriamanantema T, Rakoto FA. Neglected ameloblastoma: a case report. Med Buccale Chir Buccale 2012; 18: 161-165.

36. Zemann W, Feichtinger M, Kowatsch E, Kircher H. Extensive ameloblastoma of the jaws. Surgical management and immediate reconstruction using microvascular flaps. Oral Surg Oral Med Oral Pathol Oral Radiol Endod 2007; 103: 190-196.

37. Ruiz Valero CA, Duran-Rodriguez G, Solano-Para N, CastroNunez J. Immediate total temporomandibular joint replacement with TMJ concepts prosthesis as an alternative for ameloblastoma cases. J Oral Maxillofac Surg 2013; DOI: 10.1016/j.joms.201311.012 .

38. Daramola JO, Ajagbe HA, Akinyemi OO. Surgical complications in mandibular resection of giant ameloblastoma. J Oral Maxillofac Surg 1982; 40: 202-204.

39. Fomete B, Adebayo ET, Ogbeifun JO. Ameloblastoma: our clinical experience with 68 cases. J Orofac Sci 2014; 6: 17-24.

40. Adebayo ET, Ajike SO, Adekeye EO. A review of 318 odontogenic tumors in Kaduna, Nigeria. J Oral Maxillofac Surg 2005; 63: 811-819.

41. Collings SJ, Harrison A. Recurrent ameloblastoma. An historic case report and a review of the literature. Br Dent J 1993; 174: 202.

42. Adebayo ET, Fomete B, Adekeye EO. Soft tissue recurrence after treatment of ameloblastoma in a black African: case report and review of the literature. J Craniomaxillofac Surg 2011; 39: 615-618.

43. Infante-Cossio P, Prats-Golczer V, Gonzalez-Peres LM, et al. Treatment of recurrent mandibular ameloblastoma. Exp Ther Med 2013; 6: 579-583. 